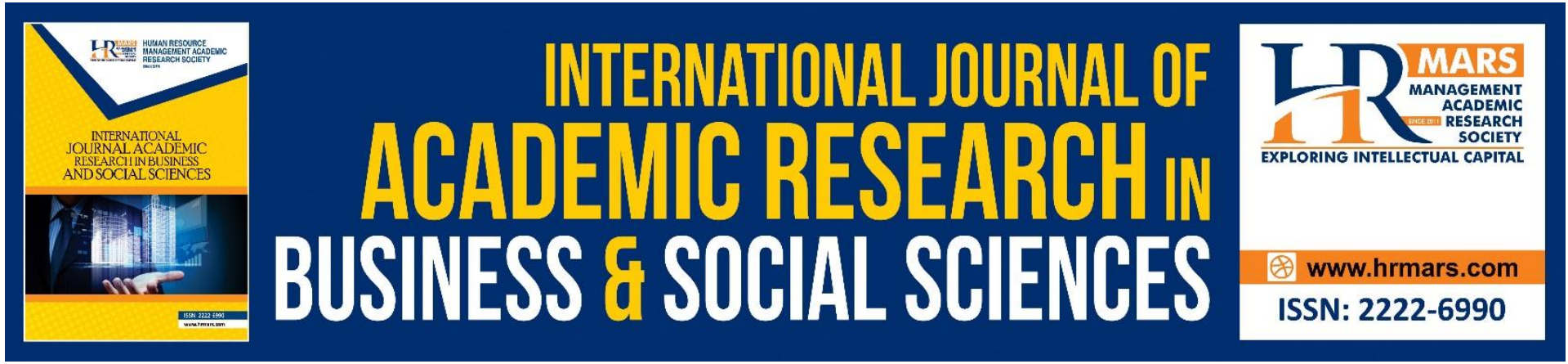

\title{
Quality of Education Provision for Orphans and Vulnerable Adolescents in The Time of Covid-19 at Orphanages
}

\author{
Nurul Nadiah Ahmad, Nurul Nazlia Jamil
}

To Link this Article: http://dx.doi.org/10.6007/IJARBSS/v11-i8/10351

DOI:10.6007/IJARBSS/v11-i8/10351

Received: 06 June 2021, Revised: 11 July 2021, Accepted: 29 July 2021

Published Online: 10 August 2021

In-Text Citation: (Ahmad \& Jamil, 2021)

To Cite this Article: Ahmad, N. N., \& Jamil, N. N. (2021). Quality of Education Provision for Orphans and Vulnerable Adolescents in The Time of Covid-19 at Orphanages. International Journal of Academic Research in Business and Social Sciences, 11(8), 605-611.

Copyright: @ 2021 The Author(s)

Published by Human Resource Management Academic Research Society (www.hrmars.com)

This article is published under the Creative Commons Attribution (CC BY 4.0) license. Anyone may reproduce, distribute, translate and create derivative works of this article (for both commercial and non-commercial purposes), subject to full attribution to the original publication and authors. The full terms of this license may be seen at: http://creativecommons.org/licences/by/4.0/legalcode

Vol. 11, No. 8, 2021, Pg. 605 - 611

Full Terms \& Conditions of access and use can be found at http://hrmars.com/index.php/pages/detail/publication-ethics 


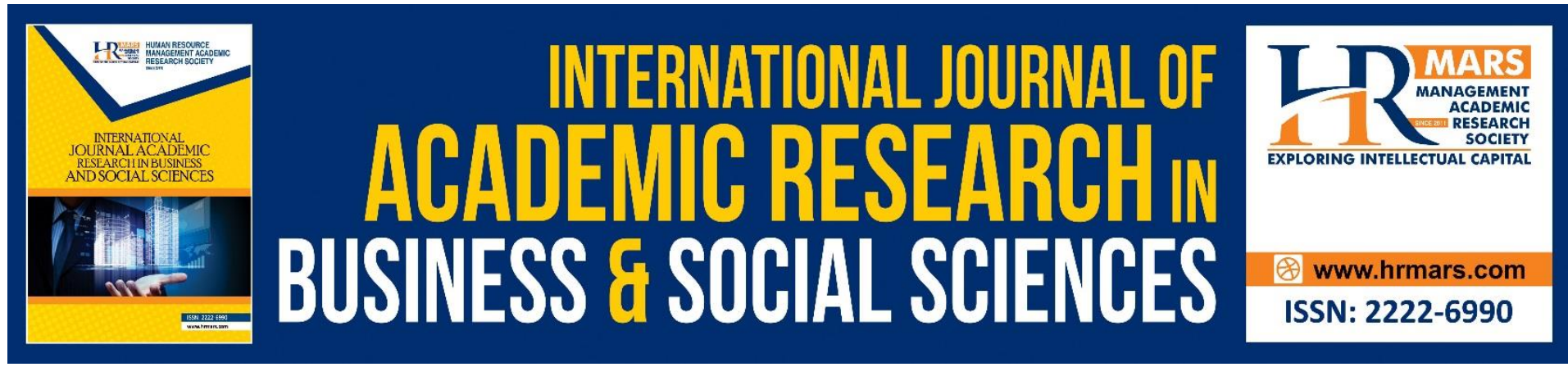

\title{
Quality of Education Provision for Orphans and Vulnerable Adolescents in The Time of Covid-19 at Orphanages
}

\author{
Nurul Nadiah Ahmad \\ College of Business Management and Accounting, Universiti Tenaga Nasional, Sultan Haji \\ Ahmad Shah Campus, Malaysia. \\ Email: Nadiahn@uniten.edu.my
}

Nurul Nazlia Jamil

Faculty of Economics and Muamalat, Universiti Sains Islam Malaysia (USIM), Malaysia

Email: nurulnazlia@usim.edu.my

\begin{abstract}
The COVID-19 virus has been recognised as a pandemic by the World Health Organization (WHO). To prevent the increased number of widespread of this virus, virtual learning has been introduced and practised at the school and university level. This virtual learning also affects the orphans and vulnerable adolescents who live at orphanages. Therefore, this study aims to examine the quality of education and performance of the orphans and vulnerable adolescents as students in Pahang orphanages. Besides, this study aims to determine the factors that affect their performance in fostering education quality. Data were collected through literatures search on virtual learning, orphans and vulnerable adolescents at orphanages during COVID-19. The core journals in virtual learning show various measurements for quality of education. Yet, the quality of education provision for orphans and vulnerable adolescents in the time of COVID-19 at orphanages still needs to be considered by measuring using (i) student factor, (ii) orphanage environment, (iii) facilities at orphanages and (iv) guardians and community involvement. The outcome of this study will provide an insight into the education quality in orphanages by highlighting their performance and its indicators. The findings could also help policymakers review the orphans and vulnerable adolescents' status to preserve social justice, particularly among children who live at orphanages.
\end{abstract}

Keywords: Education Provision, Orphans, Vulnerable Adolescents, COVID-19 Pandemic, Malaysia.

\section{Introduction}

COVID-19 virus has been spreading in China and other parts of the world since December 2019. Due to this pandemic, all students at the university or school level in Malaysia are currently missing face-to-face instruction. The students are instructed to attend the virtual 
classroom during the Movement Control Order (MCO). Many academicians have shown their concern on the students' performance when the universities and schools are asked to impose a virtual learning style (Azman et al., 2020, Kamal et al., 2020, Rasiah et al., 2020). There are also issues revolving around a larger gap between high- and low-achieving students due to the learning style transition.

This issue is also crucial for students who live at an orphanage as they are struggling to stay afloat, and they might struggle for virtual learning (Free Malaysia Today News, 2019). For instance, the poor socioeconomic climate in Nigeria has resulted in the growing population of vulnerable households and caregivers are having trouble on a daily basis in securing access to essential social services like education, food, potable water, protection, good hygiene, and good health for the children (Bamgboye et al., 2017). Besides, Khazanah (2020) highlighted that this virtual learning affected around 4.9million students nationwide. The virtual learning become more challenging when there are inadequate equipment, unconducive environments and lack of familiarity with digital technologies and e-learning among teachers, students and parents make teaching and learning.

This paper makes several contributions to the literature. At present, there is a small number of published researches that discuss quality of education and performance of the orphans and vulnerable adolescents. Past studies only focused on quality of education for the teacher and students as general (Masyhum, 2021; Samaden 2021; Yusof, 2021). Therefore, this study aimed to:

- to examine the quality of education and performance of the orphans and vulnerable adolescents through online learning at orphanages.

- to determine the factors that affect their performance in fostering the students' education quality.

The motivation for this study was driven through the lack of attention given to quality of education issues for orphans and vulnerable adolescents in the time of covid-19 at orphanages. This study selected the orphans and vulnerable adolescents who live at orphanages under the Department of Social Welfare Malaysia (JKM) as this institution put attention on the community and country development.

\section{Literature Review}

Education is a process of receiving or giving systematic instruction, especially at a school or university. In this study, three elements under education indicator, which consist of technical skills, intellectual ability, and physical ability, aim to take a closer look at orphans' education. Education is critical to individual and national well-being. Nevertheless, the orphans often face challenges in obtaining a proper education (Lingenfelter et al., 2017). The education quality has been examined by past researchers in which the previous studies gathered different factors that influence the education quality include (i) student factor, (ii) orphanage environment, (iii) facilities at orphanages and (iv) guardians and community involvement.

\section{Student Factors}

Student factor can be defined as any behaviour, attitude, or perception of students towards their study that may affect the academic performance (Semukono, \& Arinaitwe, 2013). Asfani, Suswanto, and Wibawa (2016) added that student factors are an influential factor that arises 
within the students themselves. This student factor can be evaluated through several aspects which include learning techniques, language proficiency, and personal competence (Muda et al., 2013; Ismail \& Kasim, 2011; Malgwi, 2006;). For this study, the students will be evaluated based on their background, learning techniques, language proficiency and personal competence. Students' competence typically can be observed through their performance in terms of task finalisation based on their expertise which can be influenced by motivation and learning satisfaction. Students' academic knowledge and skills can be achieved by improving their motivation to achieve success (Wentzel \& Wigfield, 1998). Students who are satisfied with their learning experiences have better academic achievement than students who feel otherwise. They will also have a positive disposition (Martirosyan, Saxon, \& Wanjohi, 2014).

\section{Orphanages Environment}

The environment can be classified as the surrounding or condition that a person lives in. In the Malaysian context, the comfort of orphanages should be a concern so that the orphans can have comfortable accommodation and conducive environment to live their life (News Straits Times, 2017). Most orphanages are facing problems with insufficient accommodation facilities and overcrowding (Yuekai, 2014). This is also evident in supporting spaces like study area, toilets, dining areas and recreational areas. The orphans are prone to get exposed to negative behaviours and abuse within the environment that they live in. Additionally, there should be a good interaction between the caregivers and the orphans in the home. In terms of the thermal and visual environment, the window to wall ratio should be adjusted to the recommended measures to ensure that naturally, these elements are enough. Otherwise, they can be artificially enhanced. Access for the physically challenged tenants should be available easily and in good condition. There should be ramps for wheelchair accessibility, as well as doors, beds, and corridor widths. Therefore, for this study, the orphanage's environment will be evaluated based on the cleanliness, maintenance, size, safety, and rules and regulations that apply to the orphans.

\section{Facilities in Orphanages}

Study facility is a factor originates from the outside of the classroom, which can interrupt the learning's daily rhythms. In terms of facilities, past study found that some facilities in orphanages tend to cater for needs other than just the provision of accommodation and others merely provide safe accommodation for the orphans (Simons \& Koranteng, 2012). For the current situation on COVID-19, facilities in orphanages must be designed with effective communication and interaction in mind. For example, the facilities, seats, table, laptop, internet, textbooks, and other teaching and learning aids, are cost-effective input in learning that will positively affect students' academic performance. Khazanah (2020) revealed that $46 \%$ owned the smartphone, only $6 \%$ have personal computer/tablet/laptop and $37 \%$ do not have any devices for virtual leaning. Besides, they still have problem on internet connectivity to have effective learning process. Due to this issue, this study will examine more on the availabilities of facilities in orphanages.

\section{Guardians and Community Involvement}

Guardians and community involvement is a catalyst for encouraging students through their learning process. All children and adolescents in Malaysian orphanages have low self-esteem and self-confidence due to lack of attention from caregivers regarding smiles, kisses, or touches (Sadho, 2015). In this light, attending schools is seen as another way of minimising 
orphans' psychological distress. Orphans viewed school as a safe place for acquiring life skills (including handling emotional problems), for grieving (through sharing experiences with others in similar situations) and for creating social networks (Nyamukapa et al., 2018). However, Malaysia government's decision to close all schools for preventing the spread of the coronavirus. Solutions for this problem provide different dimensions, and the welfare of orphans is a concern and a responsibility of everyone. It is necessary to work together with all social factors to achieve the common goal, helping orphans for their survival and development in a consistent and coordinated manner. Shukla and Shukla (2011) found that institutionalised children, even adolescences and children in foster care, have shown intellectual delays and displayed significantly more distractive behaviours. Some of them are socially-immature, and they appear emotionally-removed in terms of their capacity to form relationships. According to Clark and Mills (2011), the motivation to care and concern for others' welfare lies in building closer and supportive interpersonal relationships. It will encourage positive outcomes in their relationships, and people are motivated to care for their partner's needs and desire partners who would do the same. For instance, parents who are motivated to care about others' well-being are highly responsive to their children's needs (Le \& Impett, 2015).

\section{Conceptual Model}

Figure 1 below depicts the proposed model on assessing the quality of education and performance of the orphans and vulnerable adolescents during online learning at orphanages. This model, as in Figure 1 below, will be assessed through (i) student factor, (ii) orphanage environment, (iii) facilities at orphanages and (iv) guardians and community involvement.

Independent variables

Dependent variable

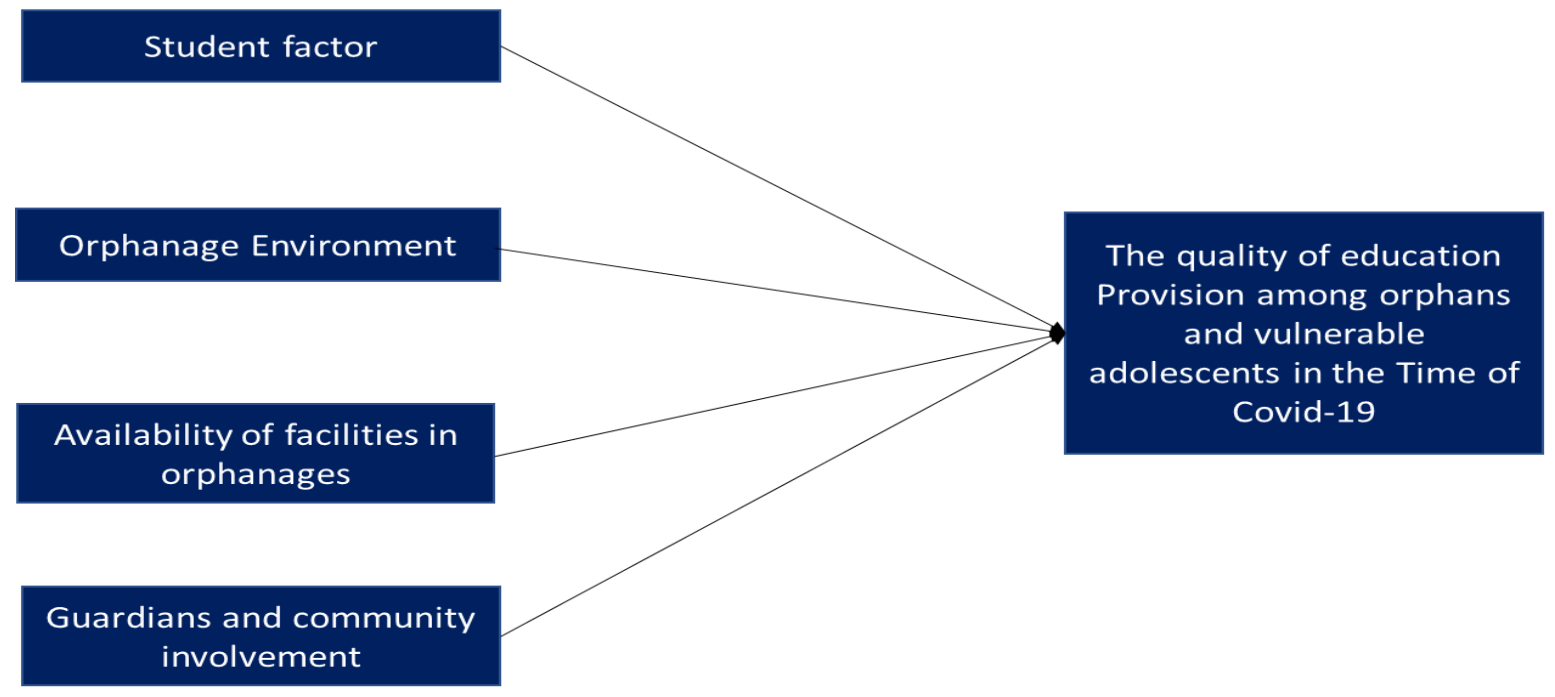

Figure 1: Research framework

\section{Conclusion}

The rapid spread of the coronavirus disease 2019 (COVID-19) outbreak has put considerable strain on the physical, social, economic, and mental well-being of student (Kannampallil et al., 2020). The objective of this study is to examine the quality of education and performance of the orphans and vulnerable adolescents through online learning at orphanages and to determine the factors that affect their performance in fostering the respondents' education 
quality. This study is aimed to provide several specific or potential applications to several stakeholders including orphans and vulnerable adolescents, guardians in orphanages and Department of Social Welfare Malaysia. This study can enhance the knowledge about the quality of education for orphans and vulnerable adolescents in the orphanages, especially during Covid-19 pandemic. This study will gain benefits to guardians by changing and enhancing the facilities at their orphanage and environment. This study gauges the extent to which the Department of Social Welfare Malaysia and the government understand the quality of education in orphanages to design appropriate activities, supports and motivational programs to cater to their needs.

\section{Acknowledgement}

The authors would like to thank the YCU grant (Project No. 202101005YCU) provided by Yayasan Canselor UNITEN (YCU).

\section{References}

Asfani, K., Suswanto, H., \& Wibawa, A. P. (2016). Influential factors of students' competence. World Transactions on Engineering and Technology Education, 14(3), 416420.

Azman, A., Singh, P. S. J., Parker, J., \& Ashencaen Crabtree, S. (2020). Addressing competency requirements of social work students during the COVID-19 pandemic in Malaysia. Social Work Education, 39(8), 1058-1065.

Clark, M. S., \& Mills, J. R. (2011). A theory of communal (and exchange) relationships. Handbook of theories of social psychology, 2, 232-250.

Free Malaysia Today News. (2018). Orphanages risk closure as donations dwindle. Retrieved 11 June 2021 from http://www.freemalaysiatoday.com/category/nation/2018/03/30/

Ismail, S., \& Kasim, N. (2011). Accounting for non-accounting students: What affects their performance?. Journal of Technical Education and Training, 3(2).

Kamal, A. A., Shaipullah, N. M., Truna, L., Sabri, M., \& Junaini, S. N. (2020). Transitioning to Online Learning during COVID-19 Pandemic: Case Study of a Pre-University Centre in Malaysia.

Kannampallil, T. G., Goss, C. W., Evanoff, B. A., Strickland, J. R., McAlister, R. P., \& Duncan, J. (2020). Exposure to COVID-19 patients increases physician trainee stress and burnout. PloS one, 15(8), e0237301.

Le, B. M., \& Impett, E. A. (2015). The rewards of caregiving for communally motivated parents. Social Psychological and Personality Science, 6(7), 758-765.

Lingenfelter, W. V., Solheim, K., \& Lawrence, A. (2017). Improving secondary education for orphans and vulnerable children in Malawi: One non-governmental organization's perspective. Child \& Youth Services, 38(2), 142-158.

Malgwi, C. A. (2006). Discerning Accounting And Non-Accounting Students'perceptions In The First Course In Accounting As A Proxy For Separate Course Delivery. Global Perspectives on Accounting Education, 3, 67.

Martirosyan, N. M., Saxon, D. P., \& Wanjohi, R. (2014). Student satisfaction and academic performance in Armenian higher education. American International Journal of Contemporary Research, 4(2), 1-5.

Masyhum, M. A. (2021). Headmasters leadership on task load and job satisfaction of special education teachers in malaysia. Turkish Journal of Computer and Mathematics Education (TURCOMAT), 12(11), 5294-5299. 
Muda, S., Hussin, A. H., Johari, H., Sapari, J. M., \& Jamil, N. (2013). The key contributing factors of non-accounting students' failure in the introduction to financial accounting course. Procedia-Social and Behavioral Sciences, 90, 712-719.

New Straits Time. (2017). Call for setting up of body to control illegal orphanages. Retrieved 11 June 2021 from https://www.nst.com.my/news/nation/2017/08/272960/callsetting-body-control-illegal-orphanages.

Nyamukapa, C. A., Gregson, S., Wambe, M., Mushore, P., Lopman, B., Mupambireyi, Z., \& Jukes, M. C. H. (2010). Causes and Consequences of Psychological Distress among Orphans in Eastern Zimbabwe. AIDS care, 22(8), 988-996.

Rasiah, R., Kaur, H., \& Guptan, V. (2020). Business Continuity Plan in the Higher Education Industry: University Students' Perceptions of the Effectiveness of Academic Continuity Plans during Covid-19 Pandemic. Applied System Innovation, 3(4), 51.

Sadho, R. (2015). How Malaysia's OrphanCARE is making sure dumped babies don't end up dead (Publication no. http://says.com/my/news/orphancare-foundation-malaysiahope-for-abandoned-babies). from SAYS.

Samaden, I. S. B. (2021). Time element in the construct of special education teacher workload in malaysia. Turkish Journal of Computer and Mathematics Education (TURCOMAT), 12(11), 5141-5145.

Semukono, F., \& Arinaitwe, A. (2013). Learning Environment, Studentsâ€ ${ }^{\mathrm{TM}}$ Attitude and Performance in Quantitative Course Units: A Focus on Business Students. Journal of Education and Vocational Research, 4(8), 238-245.

Shodimu, M. A., Yusuf, O. B., Akinyemi, J. O., Fagbamigbe, A. F., Bamgboye, E. A., Ngige, E.,\& Bashorun, A. (2017). Determinants of perceived stigmatizing and discriminating attitudes towards people living with HIV/AIDS among women of reproductive age in Nigeria. Journal of AIDS and HIV Research, 9(6), 139-151.

Shukla, B., \& Shukla, D. (2011). Study to Assess Physical Health Status of Children at Selected Orphanage in Salem, Chennai-India. IARS'International Research Journal, 1(2).

Simons, B., \& Koranteng, C. (2012). Residents' perception of the built environment quality in an orphanage.

Wentzel, K. R., \& Wigfield, A. (1998). Academic and social motivational influences on students' academic performance. Educational Psychology Review, 10(2), 155-175.

Yuekai, M. A. (2014). An Investigation into the Socio-Economic Challenges Faced By Children in Orphanages in Zimbabwe. A Case Study of Child Future Africa's Children Home, Mt. Darwin. Thesis Dissertation Department of Social Work Bindura University of Science Education.

Yusof, J. (2021). Elements of work environment in the construct of special education teacher workload in Malaysia. Turkish Journal of Computer and Mathematics Education (TURCOMAT), 12(11), 5284-5288 